\title{
Is Follow-up of Adrenal Incidentalomas Always Mandatory?
}

\author{
Giuseppe Reimondo, Alessandra Muller, Elisa Ingargiola, Soraya Puglisi, Massimo Terzolo \\ Division of Internal Medicine, Department of Clinical and Biological Sciences, San Luigi Gonzaga Hospital, University of \\ Turin, Orbassano, Italy
}

Adrenal masses are mainly detected unexpectedly by an imaging study performed for reasons unrelated to any suspect of adrenal diseases. Such masses are commonly defined as "adrenal incidentalomas" and represent a public health challenge because they are increasingly recognized in current medical practice. Management of adrenal incidentalomas is currently matter of debate. Although there is consensus on the need of a multidisciplinary expert team evaluation and surgical approach in patients with significant hormonal excess and/or radiological findings suspicious of malignancy demonstrated at the diagnosis or during follow-up, the inconsistency between official guidelines and the consequent diffuse uncertainty on management of small adrenal incidentalomas still represents a considerable problem in terms of clinical choices in real practice. The aim of the present work is to review the proposed strategies on how to manage patients with adrenal incidentalomas that are not candidates to immediate surgery. The recent European Society of Endocrinology/European Network for the Study of Adrenal Tumors guidelines have supported the view to avoid surveillance in patients with clear benign adrenal lesions $<4 \mathrm{~cm}$ and/or without any hormonal secretion; however, newer prospective studies are needed to confirm safety of this strategy, in particular in younger patients.

Keywords: Adrenal incidentaloma; Adrenal gland neoplasms; Cushing syndrome; Practice management, medical; Endocrinology.

\section{INTRODUCTION}

Adrenal masses are mainly detected unexpectedly by an imaging study performed for reasons unrelated to any suspect of adrenal diseases [1,2]. Such masses are commonly defined as "adrenal incidentalomas" and represent a public health challenge because they are increasingly recognized in current medical practice.

The frequency of adrenal incidentalomas in computed tomography (CT) series assessed in the 1980s and '90s ranged from $0.35 \%$ to $1.9 \%$ [3-8], but more recent studies have reported a frequency of about $4.2 \%$ to $7.3 \%$ [9-12] that may increase up to

Received: 18 January 2020, Revised: 24 January 2020,

Accepted: 31 January 2020

Corresponding author: Soraya Puglisi

Division of Internal Medicine, Department of Clinical and Biological Sciences, San Luigi Gonzaga Hospital, Regione Gonzole 10, Orbassano 10043, Italy Tel: +39-11-9026292, Fax: +39-11-6705456, E-mail: sorayapuglisi@yahoo.com
$10 \%$ in elderly population. The etiology of adrenal incidentalomas includes mostly benign non-secreting adenomas, however a number of lesions are malignant or are hormone producing (pheochromocytoma, aldosterone producing adenoma, and cortisol producing adenoma).

Up to $20 \%$ of patients bearing an incidental adrenal adenoma present the so-called subclinical Cushing syndrome, even if there is no consensus on how to secure the diagnosis [13-15]. In this area of controversy, we have proposed the following diagnostic criteria: first, the adrenal mass should have radiologic characteristics of adrenal adenoma; second, the patient should not present any specific Cushingoid sign; third, the endocrine 
work-up should demonstrate partial autonomous (pituitary adrenocorticotropic independent) cortisol secretion [14]. Several studies have shown that this low-grade cortisol excess may be associated with various comorbid conditions (hypertension, type 2 diabetes mellitus, obesity, dyslipidemia, and osteoporosis) $[13,16,17]$. Therefore, the term subclinical is equivocal because the condition may have clinical consequences and, for these reasons, the recent European Society of Endocrinology (ESE) guidelines abandoned the term "subclinical Cushing syndrome" for "autonomous cortisol secretion" [2].

Management of adrenal incidentalomas is currently matter of debate. There is consensus on the need of a multidisciplinary expert team evaluation and surgical approach in patients with significant hormonal excess and/or radiological findings suspicious of malignancy demonstrated at the diagnosis or during follow-up. The aim of the present work is to review the proposed strategies on how to manage patients with adrenal incidentalomas that are not candidates to immediate surgery, since there is no consensus on what type of follow-up, if any, is needed $[1,2,18-23]$.

\section{STRATEGIES OF RADIOLOGICAL FOLLOW-UP}

Available guidelines [2,18,21,23] and consensus statements $[1,19,20,22]$ diverge on indications for surveillance of benignappearing adrenal incidentalomas in order to detect malignant transformation (Table 1). The ESE/European Network for the Study of Adrenal Tumors (ENSAT) guidelines, recommend first to establish the risk of malignancy of an adrenal mass at the time of initial detection [2]. An adrenal mass is considered benign if appears homogeneous and lipid-rich, with a density $\leq 10$ Hounsfield units (HU) at an unenhanced CT scan.

For adrenal masses smaller than $4 \mathrm{~cm}$ with benign features, the ESE/ENSAT guidelines [2] and Korean guidelines [23] suggest that no further imaging is required. This is a debated point, since previous recommendations indicated the need to repeat an imaging (i.e., a CT scan) in all patients at a 3 to 6 months $[1,18,22]$, or 6 to 12 months interval [19-21]. Moreover, some guidelines recommended continuing the radiological follow-up annually [18,22], or every 2 years [20] for 4 to 5 years, without considering any mass size at diagnosis to guide the decision process for the follow-up [18-20]. The most recent recommendations extend the idea to limit follow-up introduced by the Italian "Associazione Medici Endocrinologi" (AME) position statement, that suggested to not perform any further imaging test in very small $(<1$ to $2 \mathrm{~cm})$ benign masses or in masses with clear benign features (i.e., myelolipomas, hemorrhages, cysts) $[1,21]$.

The ESE/ENSAT guidelines recommend a single follow-up test (non-contrast CT or magnetic resonance imaging) after 6 to 12 months for adrenal masses larger than $4 \mathrm{~cm}$ at diagnosis, or for adrenal masses with indeterminate characteristics, to exclude significant growth [2]. For these patients, a multidisciplinary team evaluation should identify the best option between immediate surgical treatment or additional imaging evaluation with another technique [2]. However, this is a weak recommendation supported by a very low level of evidence that leaves uncertainties in its application, since it requires a bit of personal judgment.

Benign masses are not expected to grow significantly in this time interval, but there are no evidence-based cut-offs of size increase to support suspicion of malignancy. In fact, different cut-offs of size increase that should lead to surgical resection have been proposed. A growth of $5 \mathrm{~mm}$ or of $20 \%$ in size is considered as significant and should lead to surgical resection for the ESE/ENSAT guidelines [2], while for the Canadian [21] and the Korean [23] guidelines the cut-offs are between $0.8-1 \mathrm{~cm}$ and $0.5-1 \mathrm{~cm}$, respectively (Table 1 ).

In 2017, Hong et al. [24] published a reappraisal of the ESE/ ENSAT guidelines in real clinical practice on a retrospective cohort of 1,149 patients managed at a single center in South Korea (Seoul) between 2000 and 2013 with a median follow-up of 4 years. Data were analyzed with the aim to evaluate the diagnostic value of mass size and density to detect malignant lesions. The optimal cut-off values to distinguish malignant from benign lesions were $3.4 \mathrm{~cm}$ for mass size and 19.9 HU for density at unenhanced CT. Therefore, this retrospective study validates the indication of the ESE/ENSAT guidelines to avoid any imaging follow-up in adrenal masses with density $<10 \mathrm{HU}$ and size $<4$ $\mathrm{cm}$ at unenhanced CT.

A recent systematic review and meta-analysis of the literature by Elhassan et al. [25] confirmed that most of the non-functioning adrenal adenomas and adenomas causing mild autonomous cortisol excess do not show significant growth in size during their follow-up. Only $2.5 \%$ of adrenal adenomas grew by 10 $\mathrm{mm}$ or more over an average follow-up of 41.5 months and, again, malignant transformation was never observed. This analysis pointed out that tumors $>25 \mathrm{~mm}$ had a lower rate of growth during follow-up than smaller ones, suggesting the achievement of a maximum growth potential of benign lesions [26]. The use of a growth cut-off during long term follow-up was not superior 
Table 1. Comparison among Consensus/Guidelines on Radiological Follow-up

\begin{tabular}{|c|c|c|c|c|}
\hline Consensus/Guidelines & $\begin{array}{c}\text { Year of } \\
\text { publication }\end{array}$ & Country & Recommendation/Suggestion & $\begin{array}{l}\text { Level of } \\
\text { evidence }\end{array}$ \\
\hline $\begin{array}{l}\text { National Institutes of Health }(\mathrm{NIH}) \\
\text { consensus conference [19] }\end{array}$ & 2002 & $\begin{array}{l}\text { United } \\
\text { States }\end{array}$ & $\begin{array}{l}\text { Repeat a CT scan at 6-12 months. If there is not an increase in } \\
\text { size, follow-up should be ended. }\end{array}$ & \\
\hline $\begin{array}{l}\text { Exploration and management of adrenal } \\
\text { incidentalomas. French Society of } \\
\text { Endocrinology Consensus [20] }\end{array}$ & 2008 & France & $\begin{array}{l}\text { Repeat a CT scan at } 6 \text { months to rule out the very-low risk of } \\
\text { overlooking a malignant tumor. Repeat a CT scan at } 2 \text { years and } \\
\text { at } 5 \text { years to checking for long-term malignant risk. }\end{array}$ & \\
\hline $\begin{array}{l}\text { American Association of Clinical } \\
\text { Endocrinologists/American Association } \\
\text { of Endocrine Surgeons (AACE/AAES) } \\
\text { guideline [18] }\end{array}$ & 2009 & $\begin{array}{l}\text { United } \\
\text { States }\end{array}$ & Repeat an imaging at 3-6 months and then annually for $1-2$ years & $\begin{array}{l}\text { Grade C; Evidence } \\
\text { Level } 3\end{array}$ \\
\hline \multirow[t]{2}{*}{$\begin{array}{l}\text { Guidelines for the management of the } \\
\text { incidentally discovered adrenal mass } \\
\text { [21] }\end{array}$} & 2011 & Canada & $\begin{array}{l}\text { No further imaging in patients with a benign appearing mass } \\
<1 \mathrm{~cm} \text { or in patients with benign etiologies at discovery } \\
\text { (myelolipomas, hemorrhages, cysts). }\end{array}$ & $\begin{array}{l}\text { Grade D; Evidence } \\
\text { Level } 4 \\
\text { Recommendation }\end{array}$ \\
\hline & & & $\begin{array}{l}\text { Repeat imaging after } 12 \text { months (preferably of the same modality } \\
\text { used at diagnosis) for masses of } 1-2 \mathrm{~cm} \text { if the clinical picture } \\
\text { warrants (consider no follow-up if imaging is stable). } \\
\text { Repeat imaging after } 12 \text { months for masses } 2-4 \mathrm{~cm} \text { : if stable, con- } \\
\text { sider no follow-up while if not stable consider surgical removal } \\
\text { or close follow-up ( } 3-6 \text { months). If a mass exhibits an increase } \\
\text { in size (greater than } 0.5-1 \mathrm{~cm} \text { ) consider surgical removal. }\end{array}$ & $\begin{array}{l}\text { Grade C; Evidence } \\
\text { Level } 3 \\
\text { Recommendation }\end{array}$ \\
\hline $\begin{array}{l}\text { Italian Association of Clinical } \\
\text { Endocrinologists (AME) position } \\
\text { statement [1] }\end{array}$ & 2011 & Italy & $\begin{array}{l}\text { In general, repeat a CT scan at } 3-6 \text { months. } \\
\text { No further imaging in patients with small tumors }(<2 \mathrm{~cm}) \text {. For } \\
\text { larger tumors the decision should be based on the characteristics } \\
\text { of the mass, patient age and history, results of endocrine work- } \\
\text { up. }\end{array}$ & \\
\hline $\begin{array}{l}\text { Adrenal incidentaloma in adults- } \\
\text { management recommendations by the } \\
\text { Polish Society of Endocrinology [22] }\end{array}$ & 2016 & Poland & $\begin{array}{l}\text { If the tumor is small }(\leq 3 \mathrm{~cm}) \text { and resembles a typical lipid-rich } \\
\text { adenoma, imaging tests are recommended annually. In the cases } \\
\text { of larger tumors, or those with a less characteristic phenotype, } \\
\text { consider imaging check-ups every } 3-6 \text { months within the first } \\
\text { year, and later every } 12 \text { months. } \\
\text { If the lesion is not oncological suspicious and is stable, stop } \\
\text { follow-up after } 4 \text { years. }\end{array}$ & \\
\hline $\begin{array}{l}\text { European Society of Endocrinology/ } \\
\text { European Network for the Study of } \\
\text { Adrenal Tumors (ESE/ENSAT) } \\
\text { guideline [2] }\end{array}$ & 2016 & Europe & $\begin{array}{l}\text { No further imaging in patients with an adrenal mass }<4 \mathrm{~cm} \text { with } \\
\text { clear benign features on imaging studies. } \\
\text { Repeat a non-contrast CT scan or MRI at } 6-12 \text { months in patients } \\
\text { with a mass }>4 \mathrm{~cm} \text { or with indeterminate characteristics at the } \\
\text { first imaging. } \\
\text { If there is growth of the lesion less than } 20 \% \text { of the largest } \\
\text { diameter during this period, additional imaging after } 6-12 \\
\text { months should be performed (in case of growth }>20 \% \text { and at } \\
\text { least a } 5 \text { mm increase in maximum diameter, the patient should } \\
\text { be evaluated for surgical resection). }\end{array}$ & $\begin{array}{l}\text { Weak recommen- } \\
\text { dation; Evidence } \\
\text { Level very low } \\
\text { Weak recommen- } \\
\text { dation; Evidence } \\
\text { Level very low }\end{array}$ \\
\hline $\begin{array}{l}\text { Clinical Guidelines for the Management } \\
\text { of Adrenal Incidentaloma [23] }\end{array}$ & 2017 & Korea & $\begin{array}{l}\text { No further imaging in patients with an adrenal mass }<4 \mathrm{~cm} \text { with } \\
\text { clear benign features on initial work-up. } \\
\text { Repeat a CT scan at } 3-6 \text { months and then annually for } 1-2 \text { years } \\
\text { in patients with a mass }<4 \mathrm{~cm} \text { and }>10 \mathrm{HU} \text {. } \\
\text { In case of repeated imaging follow-up, no further exams are re- } \\
\text { quired if the tumor does not change in size over a period of more } \\
\text { than } 1 \text { year, but if a mass with indeterminate radiological features } \\
\text { increases in size more than } 0.8-1 \mathrm{~cm} \text { during } 3-12 \text { months of fol- } \\
\text { low-up or it changes its appearance, consider an adrenalectomy. }\end{array}$ & $\begin{array}{l}\text { Recommendation } \\
\text { Level C }\end{array}$ \\
\hline
\end{tabular}

CT, computed tomography; MRI, magnetic resonance imaging; HU, Hounsfield unit. 
to the assessment of baseline imaging characteristics in the identification of suspicious adrenal masses [25]. This concept is confirmed in a recent, small, retrospective study reporting a tumor growth $\geq 1.0 \mathrm{~cm}$ in almost $9 \%$ of patients, even if none of them was found to be malignant [27].

Despite growing evidence is supporting the strategy suggested by the ESE/ENSAT guidelines, prospective studies are still lacking to definitively validate this approach.

\section{STRATEGIES OF BIOCHEMICAL FOLLOW- UP}

Although there is a consensus that every patient with an adrenal incidentaloma at diagnosis should undergo careful assessment including clinical examination for symptoms and signs of adrenal hormone excess and an adequate biochemical evaluation, less evidence is available on how these patients should be examined during follow-up [1,2,19-23].

At diagnosis, the ESE/ENSAT guidelines [2], following the Italian AME Position Statement [1], proposed that serum cortisol levels after $1 \mathrm{mg}$-dexamethasone suppression test (DST) $\leq$ $50 \mathrm{nmol} / \mathrm{L}(\leq 1.8 \mu \mathrm{g} / \mathrm{dL})$ safely exclude autonomous cortisol secretion. Levels between 51 and $138 \mathrm{nmol} / \mathrm{L}$ (1.9 to $5.0 \mu \mathrm{g} / \mathrm{dL})$ should be considered as evidence of 'possible autonomous cortisol secretion' and cortisol levels $>138 \mathrm{nmol} / \mathrm{L}(>5.0 \mu \mathrm{g} / \mathrm{dL})$ should be taken as evidence of 'autonomous cortisol secretion.' This cut-off is supported by studies demonstrating that patients with post-DST cortisol $>50 \mathrm{nmol} / \mathrm{L}(>1.8 \mu \mathrm{g} / \mathrm{dL})$ have increased morbidity or mortality [28,29]. Moreover, the same panel suggests to exclude pheochromocytoma by measuring plasma-free or urinary fractionated metanephrines and to exclude primary hyperaldosteronism by measuring the aldosterone/renin ratio in patients with hypertension or unexplained hypokalemia.

Reported evidence supports the idea that during follow-up patients with clinically unapparent cortisol excess very rarely develop Cushing syndrome [14,30-34], which is clearly associated with severe morbidity and elevated mortality [35-39]. The previously cited metanalysis by Elhassan et al. [25] reported that only six out of 2,745 patients with either non-functioning adrenal tumors or tumors causing mild autonomous cortisol excess developed overt Cushing syndrome. Therefore, it is plainly evident that 'autonomous cortisol secretion' is not a condition associated with a high risk to develop overt Cushing syndrome.

Nevertheless, it has been shown that low-grade autonomous cortisol excess might be associated with comorbidities (hyper- tension, glucose intolerance/type 2 diabetes mellitus, obesity, dyslipidemia, osteoporosis) [2,40], without being a preliminary stage of overt Cushing syndrome [26].

The ESE/ENSAT guidelines [2] suggest annual clinical reassessment of comorbidities related to cortisol excess in patients with 'autonomous cortisol secretion' without signs of overt Cushing syndrome and in patients with both 'possible autonomous cortisol secretion' and potentially associated comorbidities.

A critical point of discussion is how to follow the patients with a normal hormonal work-up at the initial evaluation. The ESE/ENSAT guidelines do not recommend repeating hormonal workup unless new clinical signs of endocrine activity appear, or there is worsening of comorbidities (e.g., hypertension, glucose intolerance/type 2 diabetes mellitus, obesity, dyslipidemia) [2]. This is in line with what was suggested by the Italian AME Position Statement [1] although several guidelines [18] or consensus positions $[19,20,22]$ proposed biochemical follow-up every year in all patients using different hormonal tests (Table 2). More recently, the Korean guidelines [23] recommended an annual screening for 4 to 5 years to detect a possible change in functionality of the tumors when they are larger than $2 \mathrm{~cm}$.

Hong et al. [24] in their retrospective cohort study showed that $28 \%$ of patients with non-functioning adrenal tumors at diagnosis progressed to autonomous cortisol secretion during follow-up, but none of them developed Cushing syndrome. This seems to validate the indications suggested by ESE/ENSAT guidelines, although prospective studies with a longer follow-up would be needed to confirm the appropriate follow-up strategy.

\section{IT IS CONCEIVABLE THAT NON- FUNCTIONING ADENOMAS ARE ASSOCIATED TO COMORBID CONDITIONS?}

Although the meta-analysis by Elhassan et al. [25] included studies with few patients and heterogeneous definitions of autonomous cortisol excess, it demonstrated that the prevalence of cardiovascular risk factors (such as hypertension, obesity, dyslipidemia, and type 2 diabetes) was higher than expected also in patients with non-functioning tumors. Surprisingly, mortality from cardiovascular disease during follow-up of patients with non-functioning tumors was similar to those of patients with mild autonomous cortisol secretion. Why non-functioning tumors are associated with comorbid conditions remains unclear.

It is plausible that diseased individuals are more frequently subjected to imaging tests that can lead to the detection of an 


\begin{tabular}{|c|c|c|c|c|}
\hline Consensus/Guidelines & $\begin{array}{c}\text { Year of } \\
\text { publication }\end{array}$ & Country & Recommendation/Suggestion & $\begin{array}{l}\text { Level of } \\
\text { evidence }\end{array}$ \\
\hline $\begin{array}{l}\text { National Institutes of Health (NIH) } \\
\text { consensus conference [19] }\end{array}$ & 2002 & $\begin{array}{l}\text { United } \\
\text { States }\end{array}$ & $\begin{array}{l}\text { Repeat the hormonal screening (overnight } 1 \mathrm{mg} \text { DST, urine } \\
\text { catecholamines/metabolites) annually, or earlier if clinically } \\
\text { indicated, for } 4 \text { years. }\end{array}$ & \\
\hline $\begin{array}{l}\text { Exploration and management of adrenal } \\
\text { incidentalomas. French Society of } \\
\text { Endocrinology Consensus [20] }\end{array}$ & 2008 & France & $\begin{array}{l}\text { Repeat the hormonal screening (overnight } 1 \mathrm{mg} \text { DST, plasma or } \\
\text { urinary metanephrines) at } 6 \text { months. Then repeat overnight } 1 \mathrm{mg} \\
\text { DST at } 2 \text { years and at } 5 \text { years. }\end{array}$ & \\
\hline $\begin{array}{l}\text { American Association of Clinical } \\
\text { Endocrinologists/American Association } \\
\text { of Endocrine Surgeons (AACE/AAES) } \\
\text { guideline [18] }\end{array}$ & 2009 & $\begin{array}{l}\text { United } \\
\text { States }\end{array}$ & $\begin{array}{l}\text { Repeat the hormonal screening (overnight } 1 \mathrm{mg} \text { DST, plasma al- } \\
\text { dosterone concentration and plasma renin activity, plasma free } \\
\text { metanephrine and normetanephrine, 24-hour total urinary meta- } \\
\text { nephrines and fractionates catecholamines) annually for } 5 \text { years. }\end{array}$ & $\begin{array}{l}\text { Grade C; Evidence } \\
\text { Level } 3\end{array}$ \\
\hline $\begin{array}{l}\text { Guidelines for the management of the } \\
\text { incidentally discovered adrenal mass } \\
\text { [21] }\end{array}$ & 2011 & Canada & $\begin{array}{l}\text { Clinical and hormonal follow-up using screening tests employed } \\
\text { at initial evaluation annually for } 4 \text { years. Masses exhibiting } \\
\text { increasing hyperfunction should be considered for surgery. }\end{array}$ & $\begin{array}{l}\text { Level } 3 \\
\text { Evidence, Grade C } \\
\text { Recommendation }\end{array}$ \\
\hline $\begin{array}{l}\text { Italian Association of Clinical } \\
\text { Endocrinologists (AME) position } \\
\text { statement [1] }\end{array}$ & 2011 & Italy & $\begin{array}{l}\text { Repeat the hormonal screening (i.e., overnight } 1 \mathrm{mg} \text { DST) in case } \\
\text { of development of clinical signs of hormone excess or worsening } \\
\text { of the metabolic status and cardiovascular risk profile despite } \\
\text { optimal medical treatment. }\end{array}$ & \\
\hline $\begin{array}{l}\text { Adrenal incidentaloma in adults- } \\
\text { management recommendations by the } \\
\text { Polish Society of Endocrinology [22] }\end{array}$ & 2016 & Poland & $\begin{array}{l}\text { Repeat the hormonal screening with the overnight } 1 \mathrm{mg} \text { DST } \\
\text { annually (screening tests for pheochromocytoma may be } \\
\text { considered). Stop follow-up after 3-5 years. Patients with } \\
\text { suspected subclinical hypercortisolism require more control tests. }\end{array}$ & \\
\hline $\begin{array}{l}\text { European Society of Endocrinology/ } \\
\text { European Network for the Study of } \\
\text { Adrenal Tumors (ESE/ENSAT) } \\
\text { guideline [2] }\end{array}$ & 2016 & Europe & $\begin{array}{l}\text { No further hormonal screening in patients with normal hormonal } \\
\text { work-up at initial evaluation, unless there are new clinical signs } \\
\text { of endocrine activity or worsening of comorbidities (i.e., hyper- } \\
\text { tension and type } 2 \text { diabetes). } \\
\text { Hormonal re-evaluation at any time during the annual clinical } \\
\text { follow-up in patient with 'autonomous cortisol secretion' and in } \\
\text { patients with both 'possible autonomous cortisol secretion' and } \\
\text { potentially associated comorbidities. }\end{array}$ & $\begin{array}{l}\text { Weak recommen- } \\
\text { dation; Evidence } \\
\text { Level very low }\end{array}$ \\
\hline $\begin{array}{l}\text { Clinical Guidelines for the Management } \\
\text { of Adrenal Incidentaloma [23] }\end{array}$ & 2017 & Korea & $\begin{array}{l}\text { In tumors larger than } 2 \mathrm{~cm} \text {, repeat annual hormone tests for 4-5 } \\
\text { years to check the functionality of the tumor. }\end{array}$ & $\begin{array}{l}\text { Recommendation } \\
\text { Level C }\end{array}$ \\
\hline
\end{tabular}

DST, dexamethasone suppression test.

adrenal incidentaloma. An alternative explanation is that metabolic syndrome and diabetes may promote development of adrenal tumors [41]. Finally, there is the possibility that autonomous cortisol secretion may escape detection by the available endocrine tests and lead to incorrect diagnosis of non-functioning tumors [26]. However, evidence suggests that a greater degree of cortisol autonomy, heralded by higher cortisol levels after overnight $1 \mathrm{mg}$-DST suppression, is linked to increasing cardiovascular risk $[1,2,14]$. Therefore, we need more studies to understand what level of cortisol autonomy is tied to clinical consequences. Answering this question is the key to develop adequate decision-making strategies concerning the choice be- tween surgery and conservative management for patients with adrenal incidentalomas.

\section{IS IT CONCEIVABLE AN ADENOMA TO CARCINOMA PROGRESSION?}

An important debated issue is the possibility of an adenoma to carcinoma progression. Clinical experiences are anecdotal and only few case reports are available. The only published case of a malignant progression is the description of a patient with a typical benign incidentaloma who had developed an adrenocortical carcinoma 13 years later [42]. The patient underwent 5 
years of uneventful imaging follow-up. The lesion was small, homogeneous, non-secreting, with low HU. Several years after the last CT scan, a large, right, heterogeneous adrenal mass was found incidentally. The histology examination, after surgery, showed an adrenal carcinoma without any benign area (Weiss score 8). Bernard et al. [43] described a case of a patient operated for an adrenal incidentaloma, who had at the histological examination two different areas: a central malignant tissue surrounded by an area with clear benign appearance. At molecular analysis, the malignant part had genomic abnormalities similar to other malignant tumors, while the benign did not have any mutations.

In two series of patients with a definitive diagnosis of adrenocortical carcinoma, the imaging of adrenal gland before the diagnosis of malignancy were re-evaluated. Ozsari et al. [44] analyzed 25 cases of adrenal carcinoma. Only five of these had normal glands, instead 20 patients had pre-existing masses. However, none of them had the characteristic of a benign lesion: the masses were heterogeneous, with high HU units, diameters
$>4 \mathrm{~cm}$. Thus, according to guidelines, they should have had a closer follow-up. Nogueira et al. [45] analyzed the images of 20 adrenal masses before the onset of adenocarcinoma. Excluding the larger masses, five patients had a mass less than $2 \mathrm{~cm}$ in size, and only two of them had one or more characteristics of benign lesions. However, in both cases, an unenhanced $\mathrm{CT}$ with HU evaluation has not been performed, thus we could not exclude a high density suggestive of malignancy.

The pathogenesis of a possible transformation from a benign adenoma to a malignant carcinoma remains matter of debate. A hypothesis suggests two different events that can occur in the same adrenal gland [42]. In contrast, there are data suggesting an adenoma to carcinoma sequence, with additional occurrence of mutations, as in colorectal cancer $[46,47]$. The pathway that seems to play a central role in this model is the Wnt/beta-catenin pathway. Tissier et al. [48] demonstrated that the activation of Wnt is frequent both in benign and malignant lesions in half of cases, especially in non-secreting tumors. The role of wnt/betacatenin pathway in oncogenesis have been studied particularly

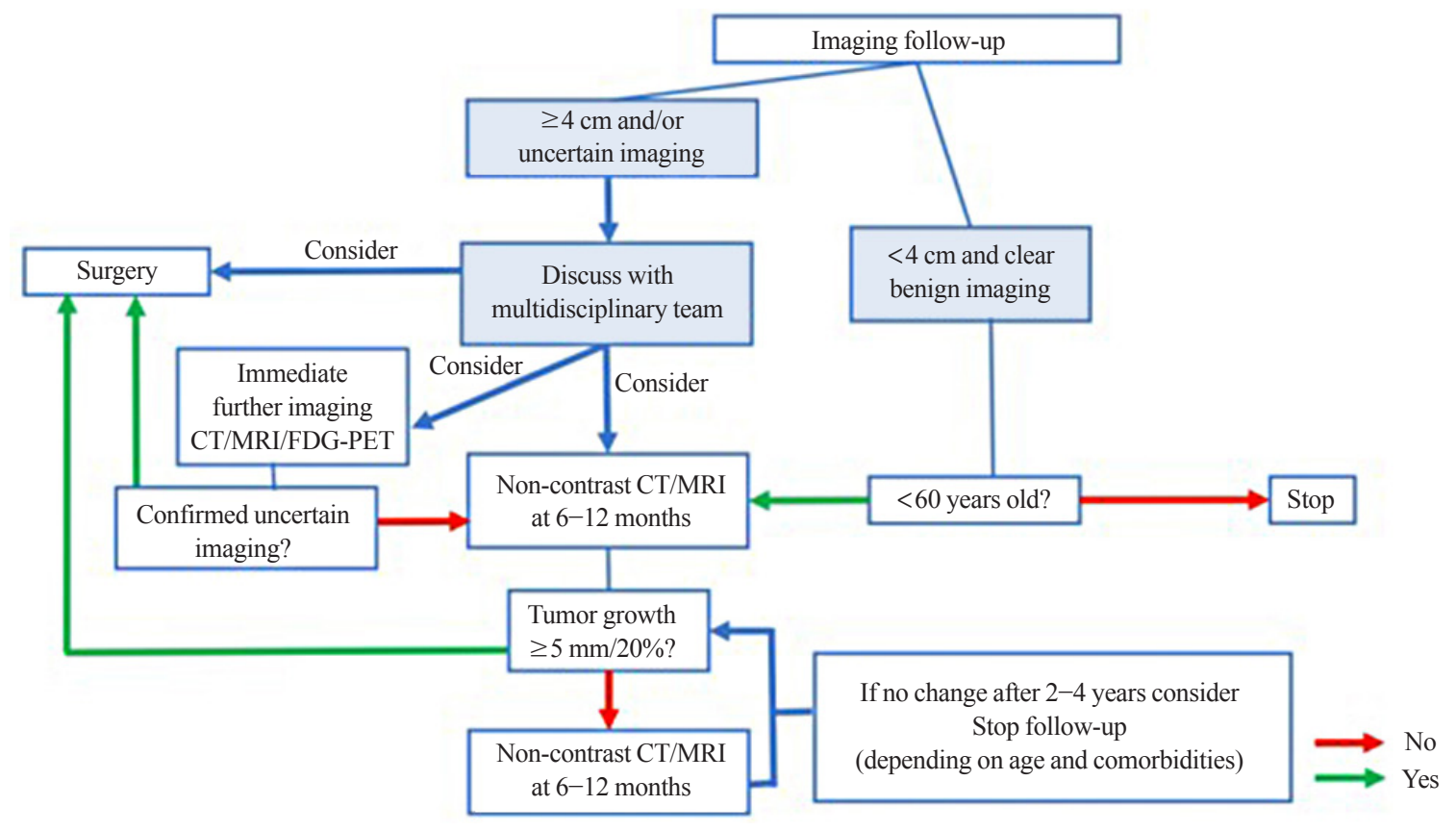

Fig. 1. Flowchart on the radiological follow-up of adrenal incidentalomas. After first radiological evaluation of adrenal masses $<4 \mathrm{~cm}$ with clear radiological benign features, we suggest no further imaging in patients ages $>60$ years. For patients aged $<60$ years, we suggest one single imaging control after 6 to 12 months. After first radiological evaluation of adrenal masses $\geq 4 \mathrm{~cm}$ and/or uncertain radiological features, three possibilities can be considered and should be discussed by a multidisciplinary team: immediate surgery, immediate further imaging with another technique or delayed radiological re-evaluation after 6 to 12 months. If the uncertain nature of the adrenal lesion is confirmed, or if the imaging follow-up shows a growth $>5 \mathrm{~mm}$ or $>20 \%$, surgery should be considered. If no changes of the lesion are observed at 6 to 12 months, radiological follow-up can be continued up to 2 to 4 years, depending on age and comorbidities of the patients, and then stopped if stability of the lesion is confirmed. CT, computed tomography; MRI, magnetic resonance imaging; FDG-PET, fluorodeoxyglucose positron emission tomography. 
in familial adenomatous polyposis (FAP), that is an autosomal dominant disease where the germline mutations of adenomatous polyposis coli $(A P C)$ gene determinate an alteration in the APC protein. Interestingly, a high incidence of adrenocortical tumors has been found in patients with FAP, many of them as autopsy findings [49]. The importance of beta-catenin pathway is demonstrated also in mice model, where the presence of stabilized beta-catenin with a second mutation triggers the process from normal adrenal gland to hyperplasia and then to adenoma and carcinoma [50].

Moreover, it has proven that adrenal gland adenomas and carcinomas presented many common copy number alterations in the entire genome. In benign adenomas the most frequent alterations were copy numbers gains, and most of them were present also in carcinomas. The more involved chromosomes were 4, 5, $7,8,12,16,19$, that encode for transcription factors, protein kinases, oncogenes, and tumor suppressor genes. Several of these are also known to be associated with beta-catenin pathway. Many of these aberrations have been reported in other type of tumors, as colorectal cancer and early stage non-small-cell lung carcinoma, where they represent a crucial step for the tumorigenesis [51].

The possibility that an adrenal adenoma progresses to carcinoma is unlikely. However, it would be important to better understand this mechanism to define how and in which patients there is more risk to malignancy, and to develop an appropriate follow-up algorithm.

\section{CONCLUSIONS}

To date, the inconsistency between official guidelines and the consequent diffuse uncertainty on management of small adrenal incidentalomas still represents a considerable problem in terms of clinical choices in real practice. Moreover, the increasing prevalence of incidentally detected adrenal masses makes this uncertainty also a matter of cost-effectiveness.

In relation to this point, Chomsky-Higgins et al. [52] developed a cost-effectiveness model, which evaluates different sur-

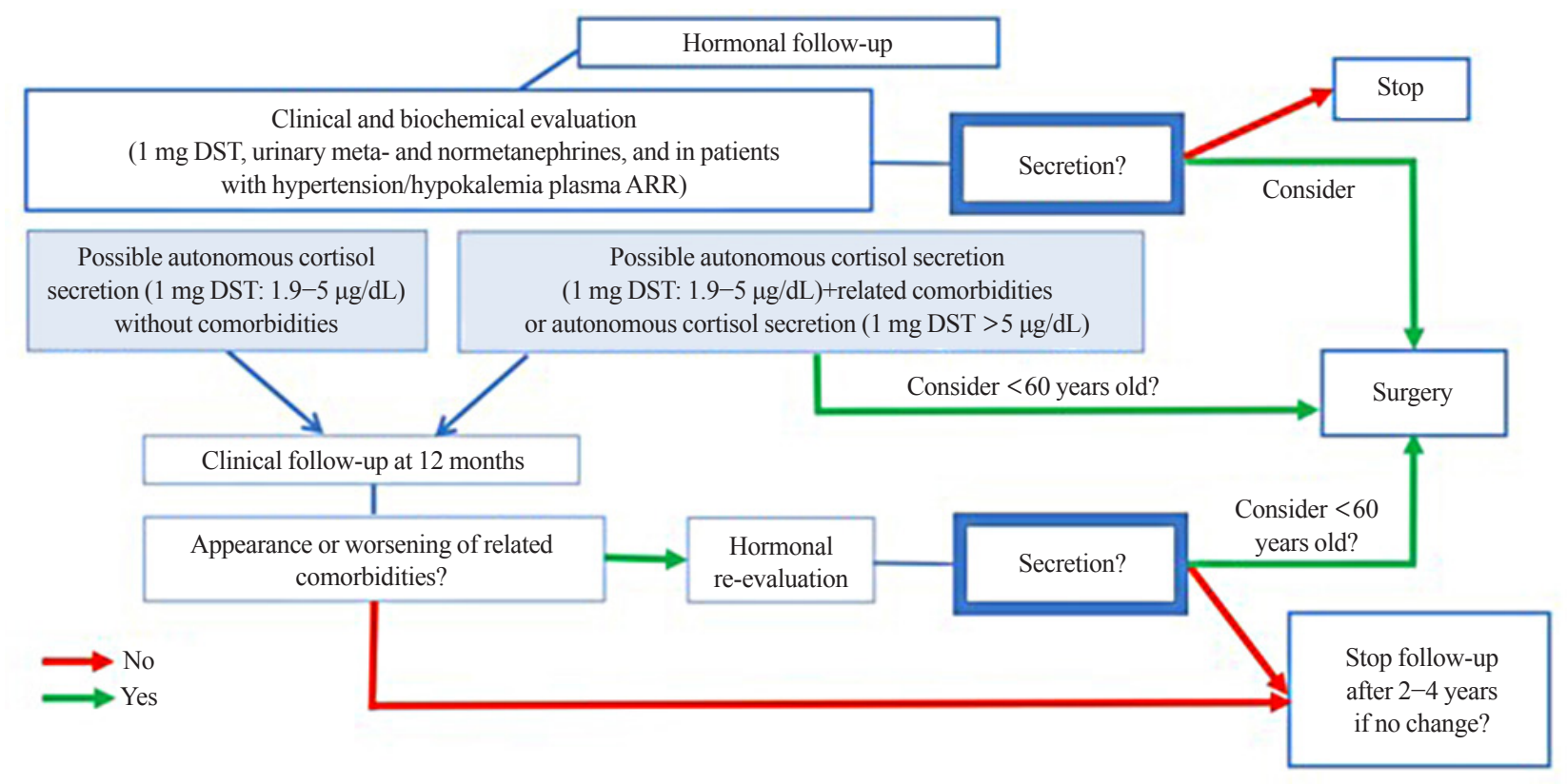

Fig. 2. Flowchart on the biochemical follow-up of adrenal incidentalomas. At first evaluation, patients with adrenal incidentaloma should undergo a clinical and biochemical evaluation for hormonal secretion, consisting of $1 \mathrm{mg}$-dexamethasone suppression test (DST), plasmafree or urinary fractionated metanephrines and aldosterone/renin ratio (ARR) in patients with hypertension or unexplained hypokalemia. If hormonal secretion at diagnosis is excluded, biochemical follow-up is not indicated. In case of overt Cushing's syndrome, pheochromocytoma or primary hyperaldosteronism, surgery should be considered. Surgery can also be considered in patients with autonomous cortisol secretion or possible autonomous cortisol secretion with related comorbidities; if surgery is not performed, patients with possible autonomous cortisol secretion without comorbidities should undergo a clinical follow-up after 12 months with a subsequent biochemical re-evaluation in case of clinical worsening. If the biochemical re-evaluation shows hormonal secretion, surgery should be considered, particularly in patients aged $<60$ years. In case of clinical and biochemical stability, biochemical follow-up can be stopped after 2 to 4 years. 
veillance strategies for management of small $(<4 \mathrm{~cm})$, benignappearing adrenal incidentalomas. Four possible strategies were compared: no surveillance, single surveillance at 12 months, annual surveillance for 2 years, and annual surveillance for 5 years. Surveillance included imaging (non-contrast CT) and biochemical testing (DST and plasma levels of renin, aldosterone, and metanephrine).

Costs were measured in 2016 United States dollars, effectiveness in quality-adjusted life-years. The results showed that the two strategies with more surveillance were less effective and more costly, because of false positives, unnecessary surgery, exposure to radiation. The strategies with no surveillance and single surveillance dominated in terms of cost-effectiveness. In particular, the single surveillance strategy was cost-effective in younger patients ( $<60$ years), whereas in older patients $(>60$ years) the no-surveillance strategy was more effective.

The authors conclude suggesting a management strategy similar to what indicated by the ESE/ENSAT guidelines, but adding a single radiological and biochemical follow-up, especially in patients aged $<60$ years.

This strategy could maybe represent a compromise between the recent European guidelines and the previous ones and help clinicians to avoid excessive surveillance, inducing unnecessary radiation or surgery, without the risk of overlooking a lesion with malignant potential hiding beyond a benign appearance at detection, and with tolerable costs for society.

Following the mainly retrospective available data we suggest a possible algorithm for the follow-up management of adrenal incidentaloma considering separately imaging and hormonal evaluation (Figs. 1, 2).

\section{CONFLICTS OF INTEREST}

No potential conflict of interest relevant to this article was reported.

\section{ORCID}

Giuseppe Reimondo https://orcid.org/0000-0001-9489-2094

Soraya Puglisi https://orcid.org/0000-0002-2883-6139

\section{REFERENCES}

1. Terzolo M, Stigliano A, Chiodini I, Loli P, Furlani L, Arnaldi G, et al. AME position statement on adrenal incidentaloma. Eur J Endocrinol 2011;164:851-70.
2. Fassnacht M, Arlt W, Bancos I, Dralle H, Newell-Price J, Sahdev A, et al. Management of adrenal incidentalomas: European Society of Endocrinology Clinical Practice Guideline in collaboration with the European Network for the Study of Adrenal Tumors. Eur J Endocrinol 2016;175:G1-34.

3. Glazer HS, Weyman PJ, Sagel SS, Levitt RG, McClennan BL. Nonfunctioning adrenal masses: incidental discovery on computed tomography. AJR Am J Roentgenol 1982;139: 81-5.

4. Prinz RA, Brooks MH, Churchill R, Graner JL, Lawrence AM, Paloyan E, et al. Incidental asymptomatic adrenal masses detected by computed tomographic scanning: is operation required? JAMA 1982;248:701-4.

5. Abecassis M, McLoughlin MJ, Langer B, Kudlow JE. Serendipitous adrenal masses: prevalence, significance, and management. Am J Surg 1985;149:783-8.

6. Belldegrun A, Hussain S, Seltzer SE, Loughlin KR, Gittes RF, Richie JP. Incidentally discovered mass of the adrenal gland. Surg Gynecol Obstet 1986;163:203-8.

7. Herrera MF, Grant CS, van Heerden JA, Sheedy PF, Ilstrup DM. Incidentally discovered adrenal tumors: an institutional perspective. Surgery 1991;110:1014-21.

8. Caplan RH, Strutt PJ, Wickus GG. Subclinical hormone secretion by incidentally discovered adrenal masses. Arch Surg 1994;129:291-6.

9. Bovio S, Cataldi A, Reimondo G, Sperone P, Novello S, Berruti A, et al. Prevalence of adrenal incidentaloma in a contemporary computerized tomography series. J Endocrinol Invest 2006;29:298-302.

10. Hammarstedt L, Muth A, Wangberg B, Bjorneld L, Sigurjonsdottir HA, Gotherstrom G, et al. Adrenal lesion frequency: a prospective, cross-sectional CT study in a defined region, including systematic re-evaluation. Acta Radiol 2010;51:114956.

11. Grossman A, Koren R, Tirosh A, Michowiz R, Shohat Z, Rahamimov R, et al. Prevalence and clinical characteristics of adrenal incidentalomas in potential kidney donors. Endocr Res 2016;41:98-102.

12. Reimondo G, Castellano E, Grosso M, Priotto R, Puglisi S, $\mathrm{Pia} \mathrm{A}$, et al. Adrenal incidentalomas are tied to increased risk of diabetes: findings from a prospective study. J Clin Endocrinol Metab 2020 Jan 4 [Epub]. https://doi.org/10.1210/clinem/ dgz284.

13. Reincke M. Subclinical Cushing's syndrome. Endocrinol Metab Clin North Am 2000;29:43-56.

14. Terzolo M, Bovio S, Reimondo G, Pia A, Osella G, Borretta 
G, et al. Subclinical Cushing's syndrome in adrenal incidentalomas. Endocrinol Metab Clin North Am 2005;34:423-39.

15. Terzolo M, Bovio S, Pia A, Osella G, Borretta G, Angeli A, et al. Subclinical Cushing's syndrome. Arq Bras Endocrinol Metabol 2007;51:1272-9.

16. Barzon L, Scaroni C, Sonino N, Fallo F, Paoletta A, Boscaro M. Risk factors and long-term follow-up of adrenal incidentalomas. J Clin Endocrinol Metab 1999;84:520-6.

17. Morelli V, Reimondo G, Giordano R, Della Casa S, Policola $\mathrm{C}$, Palmieri S, et al. Long-term follow-up in adrenal incidentalomas: an Italian multicenter study. J Clin Endocrinol Metab 2014;99:827-34.

18. Zeiger MA, Thompson GB, Duh QY, Hamrahian AH, Angelos P, Elaraj D, et al. The American Association of Clinical Endocrinologists and American Association of Endocrine Surgeons medical guidelines for the management of adrenal incidentalomas. Endocr Pract 2009;15 Suppl 1:1-20.

19. NIH state-of-the-science statement on management of the clinically inapparent adrenal mass ("incidentaloma"). NIH Consens State Sci Statements 2002;19:1-25.

20. Tabarin A, Bardet S, Bertherat J, Dupas B, Chabre O, Hamoir E, et al. Exploration and management of adrenal incidentalomas. French Society of Endocrinology Consensus. Ann Endocrinol (Paris) 2008;69:487-500.

21. Kapoor A, Morris T, Rebello R. Guidelines for the management of the incidentally discovered adrenal mass. Can Urol Assoc J 2011;5:241-7.

22. Bednarczuk T, Bolanowski M, Sworczak K, Gornicka B, Cieszanowski A, Otto M, et al. Adrenal incidentaloma in adults: management recommendations by the Polish Society of Endocrinology. Endokrynol Pol 2016;67:234-58.

23. Lee JM, Kim MK, Ko SH, Koh JM, Kim BY, Kim SW, et al. Clinical guidelines for the management of adrenal incidentaloma. Endocrinol Metab (Seoul) 2017;32:200-18.

24. Hong AR, Kim JH, Park KS, Kim KY, Lee JH, Kong SH, et al. Optimal follow-up strategies for adrenal incidentalomas: reappraisal of the 2016 ESE-ENSAT guidelines in real clinical practice. Eur J Endocrinol 2017;177:475-83.

25. Elhassan YS, Alahdab F, Prete A, Delivanis DA, Khanna A, Prokop L, et al. Natural history of adrenal incidentalomas with and without mild autonomous cortisol excess: a systematic review and meta-analysis. Ann Intern Med 2019; 171:107-16.

26. Terzolo M, Reimondo G. Insights on the natural history of adrenal incidentalomas. Ann Intern Med 2019;171:135-6.

27. Tasaki M, Kasahara T, Takizawa I, Saito K, Nishiyama T,
Tomita Y. Limited significance of repeated long-term radiological and hormonal examination in nonfunctioning adrenal incidentalomas. Int Braz J Urol 2019;45:503-13.

28. Debono M, Bradburn M, Bull M, Harrison B, Ross RJ, Newell-Price J. Cortisol as a marker for increased mortality in patients with incidental adrenocortical adenomas. J Clin Endocrinol Metab 2014;99:4462-70.

29. Di Dalmazi G, Vicennati V, Garelli S, Casadio E, Rinaldi E, Giampalma E, et al. Cardiovascular events and mortality in patients with adrenal incidentalomas that are either non-secreting or associated with intermediate phenotype or subclinical Cushing's syndrome: a 15-year retrospective study. Lancet Diabetes Endocrinol 2014;2:396-405.

30. Barzon L, Sonino N, Fallo F, Palu G, Boscaro M. Prevalence and natural history of adrenal incidentalomas. Eur J Endocrinol 2003;149:273-85.

31. Bernini GP, Moretti A, Oriandini C, Bardini M, Taurino C, Salvetti A. Long-term morphological and hormonal followup in a single unit on 115 patients with adrenal incidentalomas. Br J Cancer 2005;92:1104-9.

32. Fagour C, Bardet S, Rohmer V, Arimone Y, Lecomte P, Valli $\mathrm{N}$, et al. Usefulness of adrenal scintigraphy in the follow-up of adrenocortical incidentalomas: a prospective multicenter study. Eur J Endocrinol 2009;160:257-64.

33. Libe R, Dall'Asta C, Barbetta L, Baccarelli A, Beck-Peccoz P, Ambrosi B. Long-term follow-up study of patients with adrenal incidentalomas. Eur J Endocrinol 2002;147:489-94.

34. Nieman LK. Update on subclinical Cushing's syndrome. Curr Opin Endocrinol Diabetes Obes 2015;22:180-4.

35. Dekkers OM, Horvath-Puho E, Jorgensen JO, Cannegieter SC, Ehrenstein V, Vandenbroucke JP, et al. Multisystem morbidity and mortality in Cushing's syndrome: a cohort study. J Clin Endocrinol Metab 2013;98:2277-84.

36. Lacroix A, Feelders RA, Stratakis CA, Nieman LK. Cushing's syndrome. Lancet 2015;386:913-27.

37. Neychev V, Steinberg SM, Yang L, Mehta A, Nilubol N, Keil MF, et al. Long-term outcome of bilateral laparoscopic adrenalectomy measured by disease-specific questionnaire in a unique group of patients with Cushing's syndrome. Ann Surg Oncol 2015;22 Suppl 3:S699-706.

38. Nieman LK. Cushing's syndrome: update on signs, symptoms and biochemical screening. Eur J Endocrinol 2015;173: M33-8.

39. Nieman LK, Biller BM, Findling JW, Murad MH, NewellPrice J, Savage MO, et al. Treatment of Cushing's syndrome: an endocrine society clinical practice guideline. J 
Clin Endocrinol Metab 2015;100:2807-31.

40. Reimondo G, Puglisi S, Pia A, Terzolo M. Autonomous hypercortisolism: definition and clinical implications. Minerva Endocrinol 2019;44:33-42.

41. Sydney GI, Ioakim KJ, Paschou SA. Insulin resistance and adrenal incidentalomas: a bidirectional relationship. Maturitas 2019;121:1-6.

42. Belmihoub I, Silvera S, Sibony M, Dousset B, Legmann P, Bertagna $X$, et al. From benign adrenal incidentaloma to adrenocortical carcinoma: an exceptional random event. Eur J Endocrinol 2017;176:K15-9.

43. Bernard MH, Sidhu S, Berger N, Peix JL, Marsh DJ, Robinson BG, et al. A case report in favor of a multistep adrenocortical tumorigenesis. J Clin Endocrinol Metab 2003;88:9981001.

44. Ozsari L, Kutahyalioglu M, Elsayes KM, Vicens RA, Sircar $\mathrm{K}$, Jazaerly $\mathrm{T}$, et al. Preexisting adrenal masses in patients with adrenocortical carcinoma: clinical and radiological factors contributing to delayed diagnosis. Endocrine 2016;51: 351-9.

45. Nogueira TM, Lirov R, Caoili EM, Lerario AM, Miller BS, Fragoso MC, et al. Radiographic characteristics of adrenal masses preceding the diagnosis of adrenocortical cancer. Horm Cancer 2015;6:176-81.

46. Luft FC. Inherited colon cancer as an example of a multistep process model. J Mol Med (Berl) 1996;74:487-8.

47. Al-Sohaily S, Biankin A, Leong R, Kohonen-Corish M, Warusavitarne J. Molecular pathways in colorectal cancer. J Gastroenterol Hepatol 2012;27:1423-31.

48. Tissier F, Cavard C, Groussin L, Perlemoine K, Fumey G, Hagnere AM, et al. Mutations of beta-catenin in adrenocortical tumors: activation of the Wnt signaling pathway is a frequent event in both benign and malignant adrenocortical tumors. Cancer Res 2005;65:7622-7.

49. Bonnet-Serrano F, Bertherat J. Genetics of tumors of the adrenal cortex. Endocr Relat Cancer 2018;25:R131-52.

50. Heaton JH, Wood MA, Kim AC, Lima LO, Barlaskar FM, Almeida MQ, et al. Progression to adrenocortical tumorigenesis in mice and humans through insulin-like growth factor 2 and $\beta$-catenin. Am J Pathol 2012;181:1017-33.

51. Ronchi CL, Sbiera S, Leich E, Henzel K, Rosenwald A, Allolio B, et al. Single nucleotide polymorphism array profiling of adrenocortical tumors: evidence for an adenoma carcinoma sequence? PLoS One 2013;8:e73959.

52. Chomsky-Higgins K, Seib C, Rochefort H, Gosnell J, Shen WT, Kahn JG, et al. Less is more: cost-effectiveness analysis of surveillance strategies for small, nonfunctional, radiographically benign adrenal incidentalomas. Surgery 2018; 163:197-204. 